\title{
Chemical Oxygen Demand Fractionation of Primary Wastewater Effluent for Process Optimization and Modelling
}

\author{
Thandeka Y.S. Jwara, Paul Musonge and Babatunde F. Bakare
}

\begin{abstract}
Traditionally, the complexity associated with implementing and controlling biological nutrient removal (BNR) in wastewater works (WWW) has been primarily in terms of balancing competing requirements for nitrogen and phosphorus removal, particularly with respect to the use of influent chemical oxygen demand (COD) as a carbon source for the microorganisms. Successful BNR optimization and modelling using WEST (Worldwide Engine for Simulation and Training) depends largely on the accurate fractionation of the influent COD.

The different COD fractions have differing effects on the BNR process and therefore the influent characteristics need to be well understood. This study presents the fractionation results of primary wastewater effluent COD at one of South Africa's wastewater works treating $65 \mathrm{ML} /$ day of mixed industrial and domestic effluent. The method used for COD fractionation was the oxygen uptake rate/respirometry method.

The breakdown of the results of the analysis is as follows: $70.5 \%$ biodegradable COD (bCOD) and $29.5 \%$ of non-biodegradable COD (iCOD) in terms of the total COD. Further fractionation led to a readily biodegradable soluble fraction (SS) of $52.87 \%$, a slowly degradable particulate fraction (Xs) of $17.63 \%$, a particulate nonbiodegradable fraction $\left(\mathrm{X}_{\mathrm{I}}\right)$ of $14.99 \%$ and a non-biodegradable soluble fraction $\left(\mathrm{S}_{\mathrm{I}}\right)$ of $14.51 \%$.

The fractionation results demonstrate that the primary effluent has good COD characteristics as shown by the high level of the bCOD fraction with Ss being higher than Xs. This means that the microorganisms have sufficient substrate for the BNR process and that these components can now serve as inputs to the WEST Model for the plant under study.
\end{abstract}

Keywords - chemical oxygen demand, COD fractionation, wastewater modelling, wastewater optimization, wastewater treatment

\section{INTRODUCTION}

The biological treatment of wastewater has evolved considerably from simple treatment systems that solely practice removal of organic matter to ones that include either nitrification/denitrification (N/DN) and / or phosphorus (P) removal processes. Many countries worldwide are currently facing severe freshwater resource shortages due to increasing

Manuscript received October 19, 2020. This work was supported in part by the Institute of System Science, Durban University of Technology, Durban, South Africa

Thandeka Y.S. Jwara, is with the Institute of System Science, Durban University of Technology, Durban, South Africa.

Paul Musonge is with the Institute of System Science, Durban University of Technology, Durban, South Africa.

Babatunde F. Bakare is with the Department of Chemical Engineering, Mangosuthu University of Technology, Durban, South Africa population, rapid economic growth, and extreme weather events brought on by climate change. In particular, the scarcity of fresh water is a great concern in countries where natural water resources are limited. For this reason, wastewater treatment plays an essential role in fresh water resource preservation [1].

Enhanced biological treatment processes have been developed to protect water resources from the eutrophic and toxic characteristics of pollutants present in wastewater and stringent discharge limits have been imposed on wastewater treatment plants (WWTPs). The organic matter in wastewater is expressed as chemical oxygen demand (COD) and N/DN are the ammonia/nitrate and nitrogen removal processes. These advancements increased the complexity of activated sludge mathematical models widely known as ASMs [2]. The ASMs developed recently to simulate these processes [3], [4] are based on the division of COD in the wastewater into various fractions i.e. biodegradable (bCOD), inert (iCOD), readily biodegradable $\left(\mathrm{S}_{\mathrm{S}}\right)$, slowly biodegradable $\left(\mathrm{X}_{\mathrm{S}}\right)$, soluble (SI) and particulate $\left(\mathrm{X}_{\mathrm{I}}\right)$ inert $\mathrm{COD}$, and a heterotrophic biomass fraction $\left(\mathrm{Y}_{\mathrm{H}}\right)$. The division of biodegradable COD into $S_{S}$ and $X_{S}$ was first introduced to explain the dynamics of oxygen demand of activated sludge systems. $S_{S}$ and $X_{S}$ are fractions of bCOD and are essentially the fractions that impose an oxygen demand during the wastewater treatment process or any receiving water resource [5].

Within this context and in accordance with microbial degradation kinetics, the $\mathrm{S}_{\mathrm{S}}$ consists of comparatively smaller biodegradable particles, which are easily transported across cell membrane and then metabolized in minutes as substrate for the microorganisms. On the other hand, utilization of the $\mathrm{X}_{\mathrm{S}}$ takes longer since these constituents comprise of larger particles and require extracellular breakdown prior to their transport into the cells for biodegradation [6], [7]. The soluble inert COD fraction $\left(\mathrm{S}_{\mathrm{I}}\right)$ embodies a variety of compounds which are dissolved, thus having access to the microbial cell interior, but cannot be biodegraded due to their refractory nature within a reasonable time span. Moreover, the $S_{I}$ corresponds to the bulk of microbial end-products excreted from the cells without further utilization [6], [8]. In this respect, COD fractionation is significant for ASMs as the wastewater characteristics within certain regions varies and the response of biomass in activated sludge varies with particle size of these constituents [9].

According to [10] the theoretical COD concentration of a given substance can be calculated from an oxidation equation (1). Ethanol as the given substance, the COD can be calculated using the following equation:

$$
\mathrm{C}_{2} \mathrm{H}_{6} \mathrm{O}+3 \mathrm{O}_{2} \rightarrow 2 \mathrm{CO}_{2}+3 \mathrm{H}_{2} \mathrm{O}
$$


Which means, $46 \mathrm{~g}$ of ethanol requires $96 \mathrm{~g}$ of oxygen for the full oxidation to carbon dioxide and water. The theoretical COD of ethanol is therefore $96 / 46=2.09$.

The World Engine for Simulation and Training (WEST) package has inbuilt ASMs and provides a modelling and simulation environment for wastewater treatment plants (WWTPs) to develop plant specific models. The models developed are used to assist in setting conditions for the optimization and design of the wastewater treatment process [11]. The basis for the design and optimization of wastewater treatment processes is a properly prepared balance of pollutants in the raw influent and primary effluent. The effectiveness of these processes is determined by the content of biodegradable substances, which are a source of energy (substrate) or a building material for microorganisms [12].

Various methods have been proposed for COD fractionation. The original one, the flow-through activated sludge process method, proposed by [13], has proved to be efficient but is time consuming and requires a complex pilot plant. The principle is the measurement of the Oxygen Uptake Rate (OUR) in an activated sludge process operated under daily cyclic square-wave loading conditions [14]. Batch experiments have proven more useful in estimating the organic biodegradable fractions.

Determining the COD fractions allows for the assessment of the quantity of non-biodegradable pollutants which decrease the effectiveness of biological treatment. Therefore, in the design and modelling of biogenic component removal systems, it is preferable to use the total COD (TCOD) in primary effluent divided into soluble and particulate fractions [15].

The division of COD in wastewater into fractions is shown in Fig. 1

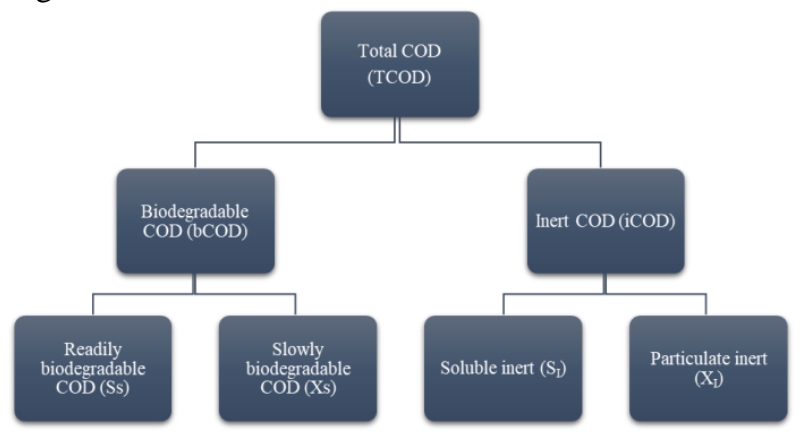

Fig. 1 Distribution of the COD fractions

The TCOD of wastewater, divided into fractions, can be calculated in a simplified way [12]:

$\mathrm{TCOD}=\mathrm{S}_{\mathrm{S}}+\mathrm{S}_{\mathrm{I}}+\mathrm{X}_{\mathrm{S}}+\mathrm{X}_{\mathrm{I}}\left(\mathrm{g} \mathrm{O}_{2} / \mathrm{m}^{3}\right)$

where:

$\mathrm{S}_{\mathrm{S}}$ - Readily biodegradable COD substrates (soluble),

$\mathrm{S}_{\mathrm{I}}$ - Soluble inert organic COD substrates,

$\mathrm{X}_{\mathrm{S}}$ - Slowly biodegradable COD substrates (particulate),

$X_{I}$ - Particulate inert COD substrates,

Table I Share of COD fraction in municipal raw wastewater and municipal wastewater with a significant share of industrial wastewater.
TABLE I SHARE OF COD FRACTION IN MUNICIPAL RAW WASTEWATER WITH A SIGNIFICANT SHARE OF INDUSTRIAL WASTEWATER.

COD Fractions \%

\begin{tabular}{|c|c|c|c|c|}
\hline $\mathbf{S S}$ & SI & XS & XI & Reference \\
\hline $\mathbf{1 0 - 2 0}$ & $7-11$ & $53-60$ & $7-15$ & {$[12]$} \\
\hline $\mathbf{9}$ & 4 & 77 & 10 & {$[16]$} \\
\hline $\mathbf{5 0 - 6 1 . 7}$ & $2.2-6$ & $22-34.4$ & $8-16$ & {$[12]$} \\
\hline $\mathbf{2 0 - 2 5}$ & $8-10$ & $60-65$ & 5.7 & {$[15]$} \\
\hline $\mathbf{2 4 - 3 2}$ & $8-11$ & $43-43-49$ & $11-20$ & {$[14]$} \\
\hline $\mathbf{3 6}$ & 4 & 40 & 20 & {$[12]$} \\
\hline
\end{tabular}

Municipal wastewater with a significant share of industrial water

\begin{tabular}{|c|c|c|c|c|}
\hline \multicolumn{7}{|c|}{ Textile industry wastewater } \\
\hline $\mathbf{2 5}$ & 14 & 59 & 2 & {$[17]$} \\
\hline $\mathbf{3 8 . 8}$ & 2.3 & 45.5 & 14.8 & {$[12]$} \\
\hline & Baking industry wastewater \\
\hline $\mathbf{3 8 . 8}$ & 1 & 44.2 & 15.2 & {$[18]$} \\
\hline $\mathbf{5}$ & \multicolumn{5}{|c|}{ Oil processing wastewater } \\
\hline $\mathbf{2 9 . 2}$ & 9.9 & 37.4 & 23.5 & {$[19]$} \\
\hline $\mathbf{4 . 2}$ & 39.5 & 43.1 & 13.2 & {$[20]$} \\
\hline
\end{tabular}

The aim of this study is to fractionate the primary wastewater effluent COD from the primary treatment stage in one of South Africa's WWTP to provide fractions that will serve as input in the WEST for optimization and modelling. The Ss, $\mathrm{Xs}, \mathrm{S}_{\mathrm{I}}$ and $\mathrm{X}_{\mathrm{I}}$ fractions were determined using the OUR batch respirometry method.

\section{METHOD}

The study focuses on a centralized WWTP which is situated in the KwaZulu-Natal Province of South Africa. The WWTP receives mixed effluents i.e. domestic wastewater and effluent from nearby industries. The industries that discharge into the WWTP are largely Oil and Dairy. The WWTP is compelled to treat wastewater that is of acceptable final effluent quality that should be devoid of excess organics - COD, ammonia $\left(\mathrm{NH}_{3}\right)$, nitrogen and $\mathrm{P}$ nutrients and is subject to comply with the national legislative requirements of the Department of Water and Sanitation (DWS).

TABLE II WWTP DISCHARGE LIMITS AS PER DISCHARGE LICENSE BY DWS

\begin{tabular}{|l|l|l|}
\hline Determinants & Units & Value \\
\hline $\begin{array}{l}\text { Chemical Oxygen Demand } \\
(\mathrm{COD})\end{array}$ & $\mathrm{mg} \mathrm{O} 2 / 1$ & 75 \\
\hline Ammonia $\left(\mathrm{NH}_{3}\right)$ & $\mathrm{mg} \mathrm{N} / 1$ & 6 \\
\hline Nitrates $\left(\mathrm{NO}_{3}\right)$ & $\mathrm{mg} \mathrm{N} / 1$ & 15 \\
\hline $\begin{array}{l}\text { Soluble Reactive Phosphorus } \\
\text { (SRP) }\end{array}$ & $\mathrm{ug} \mathrm{P} / \mathrm{l}$ & 1000 \\
\hline Suspended Solids (SS) & $\mathrm{mg} \mathrm{SS} / 1$ & 25 \\
\hline
\end{tabular}


The aim of the research was to determine the COD fractions in primary wastewater flowing into the activated sludge reactor using the OUR batch respirometry method. The OUR batch respirometry method is based on the measurement of the microbial response during substrate degradation in a batch type reactor. The recorded consumption rate of the dissolved oxygen in the batch test is closely related to the quality and quantity of available substrate in the system.

The results and calculations obtained have made it possible to determine the percentage of the individual fractions in TCOD, as well as an assessment of the practical use of the COD fraction in engineering practice.

\section{Sampling approach}

A sampling program in which daily (hourly) composite samples (substrate) were collected from the primary wastewater effluent (after primary clarifiers) using an autosampler. A sludge inoculum was collected at the end of the activated sludge reactor to ensure that there is a low risk of having residual bCOD. The collected activated sludge was aerated for a minimum of 24 hours' prior to use. This allowed it to reach a phase which indicates the oxygen consumption rate in the absence of substrate from external sources (endogenous phase). The sample was thereafter filtered to remove any large particles.

\section{Experimental approach}

In the research approach adopted for this study, a respirometer was used to conduct the experiments. The respirometry method is based on the OUR produced by the microorganisms contained in the activated sludge inoculum to biodegrade a carbonaceous substrate. It works on a closed circuit batch mode. A litre of the filtered sludge was used in the respirometer. The test was done in 4 stages.

- Stage 1: The determination of the heterotrophic yield using Acetate.

- $\quad$ Stage 2: The determination of bCOD by the addition of the $50 \mathrm{ml} 24 \mathrm{~h}$ composite sample.

- $\quad$ Stage 3: Determination of Ss by the addition of the filtered $(0,45 \mu \mathrm{m})$. $24 \mathrm{~h}$ composite sample.

- $\quad$ Stage 4: $X_{I}$ and $S_{I}$ fractions are deduced through mathematical deduction from all the experimentally/lab determined fractions.

Stage 1: The determination of the heterotrophic yield using Acetate.

The heterotrophic yield determines both the mass of electron acceptor utilized and the new cell biomass produced in the activated sludge reactor. A 1-liter solution of $400 \mathrm{mg}$ of sodium acetate was prepared in distilled water. A COD value (CODac $\approx 300 \mathrm{mg} / \mathrm{l}$ ) was obtained from the lab using standard methods. The respirometry experiment determined the consumed oxygen (CO) due to the breakdown of acetate. A 50 $\mathrm{ml}$ sample of the acetate solution was added to the 1 litre endogenous activated sludge. Once the respirometry test was completed it was considered that the acetate in solution has been completely broken-down.

CO: Consumed oxygen $=\Delta \mathrm{O}_{2}(\mathrm{mg} / \mathrm{l})$

$$
\mathrm{Y}_{\mathrm{H}, \mathrm{COD}}=1-\mathrm{COac} / \mathrm{CODac}
$$

Where:

$\mathrm{Y}_{\mathrm{H}, \mathrm{COD}}$ - Heterotrophic yield coefficient (mg O2/mg COD).

Stage 2: The determination of bCOD by the addition of the 50 $\mathrm{ml} 24 \mathrm{~h}$ composite sample.

A $50 \mathrm{ml}$ composite sample was used as substrate and its total COD concentration was determined using standard methods. 1-Allyl-2-Thiourea was used at a ratio of 2:1 to sludge MLSS to inhibit nitrification so that only the carbonaceous oxygen consumption is determined. The sludge mixture was continuously aerated with dissolved oxygen measured every 2 seconds until the process was observed to be completed. The dissolved oxygen concentration decreased as the amount of consumed oxygen increased. The consumed oxygen becomes a resultant effect of the microorganisms' respiration in the activated sludge, from the biological oxidation of the substrate (organic or ammonium) and from its own survival consumption (endogenous respiration). The test was observed to be complete when the initial dissolved oxygen (DO) was equal to the final DO. Each batch runs as long as there is still a response in consumed oxygen (approx. $50 \mathrm{~min})$.

Through this experiment the amount of bCOD in the sample was calculated using the amount of the consumed oxygen.

$$
\mathrm{bCOD}=\mathrm{CO}_{\mathrm{bCOD}} /\left(1-\mathrm{Y}_{\mathrm{H}, \mathrm{COD}}\right)=\mathrm{mg} / \mathrm{l}
$$

where:

$\mathrm{CO}_{\mathrm{bCOD}}$ - Consumed oxygen due to the breakdown of the $24 \mathrm{~h}$ composite sample

From the amount of bCOD determined a percentage could thereafter be derived from the total COD concentration of the $24 \mathrm{hr}$ composite sample that was analysed in the lab using standard methods.

$\% \mathrm{bCOD}=\left(\mathrm{bCOD} / \mathrm{COD}_{\mathrm{COMP}}\right) * 100$

The iCOD was deduced from the TCOD and bCOD concentration

Where

$$
\begin{gathered}
\mathrm{iCOD}=\mathrm{COD}_{\mathrm{COMP}}-\mathrm{bCOD} \quad \text { and } \\
\% \mathrm{iCOD}=100-\% \mathrm{bCOD}
\end{gathered}
$$


Stage 3: Determination of Ss by the addition of the filtered 24h composite sample

The stage 2 procedure was followed to determine the Ss concentration and a $50 \mathrm{ml}$ filtered $(0.45 \mu \mathrm{m})$ composite sample was used as substrate.

The experiment yielded a consumed oxygen concentration through the breakdown of the filtered sample. The concentration of Ss was determined:

$\mathrm{Ss}=\mathrm{CO}_{\mathrm{rbCOD}} /(1-\mathrm{YH}, \mathrm{COD})$

Where:

$\mathrm{CO}_{\mathrm{rbCOD}}$ - Consumed oxygen due to the breakdown of the $24 \mathrm{~h}$ filtered composite sample

The TCOD concentration and the Ss concentration are used to determined Ss percentage (\%Ss)

$\% \mathrm{Ss}=(\mathrm{Ss} / \mathrm{TCOD}) * 100$

It is from here that the Xs was deduced from the bCOD and Ss concentration as:

$\mathrm{Xs}=\mathrm{Ss}-\mathrm{bCOD}$

Resulting in a $\% \mathrm{Xs}=\mathrm{X}_{\mathrm{S}} / \mathrm{TCOD}$

Stage 4: $X_{I}$ and $S_{I}$ fractions are deduced through mathematical reduction from all the experimentally/lab determined fractions

$$
\mathrm{S}_{\mathrm{I}}=\mathrm{COD}_{\mathrm{TS}}-\mathrm{S}_{\mathrm{S}}
$$

Where:

$\mathrm{COD}_{\mathrm{TS}}-$ The total soluble COD in the composite sample as per lab analysis using standard methods

$$
\mathrm{X}_{\mathrm{I}}=\mathrm{iCOD}-\mathrm{S}_{\mathrm{I}}
$$

Where:

iCOD - The inert COD fraction deduced through mass balance using the total COD of the composite less the bCOD.

Resulting in a $\% \mathrm{X}_{\mathrm{I}}=\mathrm{X}_{\mathrm{I}} / \mathrm{TCOD}$

\section{RESULTS AND DISCUSSION}

A sample of experimental data from a COD fractionation experiment is presented in this section where the OUR response is also noted.

\begin{tabular}{|c|c|c|c|}
\hline $\begin{array}{l}\text { CODcomp } \\
(\mathrm{mg} / \mathrm{l})\end{array}$ & 440 & $\mathrm{COD}_{\mathrm{TS}}(\mathrm{mg} / \mathrm{l})$ & 205 \\
\hline & $\begin{array}{c}\text { Consumed } \\
\text { Oxygen } \\
(\mathrm{mgO} / \mathrm{l})\end{array}$ & $\begin{array}{c}\text { COD } \\
\text { Concentration } \\
(\mathrm{mg} / \mathrm{l})\end{array}$ & $\begin{array}{c}\text { Percentage } \\
\text { fraction } \\
(\%)\end{array}$ \\
\hline$Y_{H}$,acetate & 117.71 & 320 & 63 \\
\hline bCOD & 97.9 & 266.2 & 60.5 \\
\hline iCOD & & 173.8 & 39.5 \\
\hline Ss & 62.63 & 170.26 & 63.96 \\
\hline $\mathbf{X s}$ & & 173.8 & 36.04 \\
\hline $\mathbf{S}_{\mathbf{I}}$ & & 34.74 & 20 \\
\hline $\mathbf{X}_{\mathbf{I}}$ & & 139.06 & 80 \\
\hline
\end{tabular}

TABLE III SAMPLE OF EXPERIMENTAL RESULTS OF STUDY

Acetate, which is readily biodegradable in its nature was used as a reference substrate for assessing the bioactivity of the endogenous sludge in the batch reactor. The heterotrophic yield is used as basis for all experimental calculations on the endogenous sludge sample (

Table ) for finding the COD fractions as the heterotrophic yield indicates the biomass available in the reactor to breakdown substrate during the experiment.

The accepted standard heterotrophic yield value of 0.67 $\mathrm{mgCOD} / \mathrm{mgCOD}$ is used in ASMs and similar models [21] and the value of $0.63 \mathrm{mgO}_{2} / \mathrm{mgO}_{2}$ is the yield coefficient suggested by [3] for aerobic/anoxic reactions involving activated sludge. The experimental yield was found to be 0.63 $\mathrm{mgCOD} / \mathrm{mgCOD}$ which is well within range and similar to the expected literature values. High yield coefficients calculated are due to the presence of polyphosphate accumulating organisms which take up and store some of the available acetate. This is believed to be prevalent in biomass that has been growing under dynamic conditions [2].

The oxygen utilization responses noted for Fig. 2-7, are triggered by the presence of a substrate and/or the electron acceptor. Since no other exogenous substrates were added during each experiment into the batch reactors, all responses were considered to be due to the utilization of endogenous products released by the bacterial cells attached to the sludge.

The instantaneous decline response of the DO concentration is noted in all experiments (Fig. 2, Fig. 4 and 
Fig. 6). This denotes the consumption of oxygen in the reactor. The continuous diffusion of oxygen by the respirometer prevents the depletion of $\mathrm{DO}$ in the reactor during the experiment. The substrate exerts an oxygen demand and once completely broken down the DO in the reactor is seen to increase in all the experiments. The time each experiment takes depends on the nature of the substrate. Substrates which have a higher percentage of particulates take a longer time to biodegrade and typically exert a higher oxygen demand on the wastewater works.

There is a notable steady increase of the consumed oxygen curve in response to the addition of the substrate ( Fig. 3, Fig. 5 and Fig. 7 ) and after some time the curve becomes constant and no further changes in consumed oxygen are noted. This is indicative of the complete breakdown of substrate in the system and therefore from the experimental data a value of the amount of consumed oxygen due to the breakdown of acetate can be determined. The added allyl-thio urea inhibitor ensured that the response observed was particularly due to the breakdown of the bCOD.

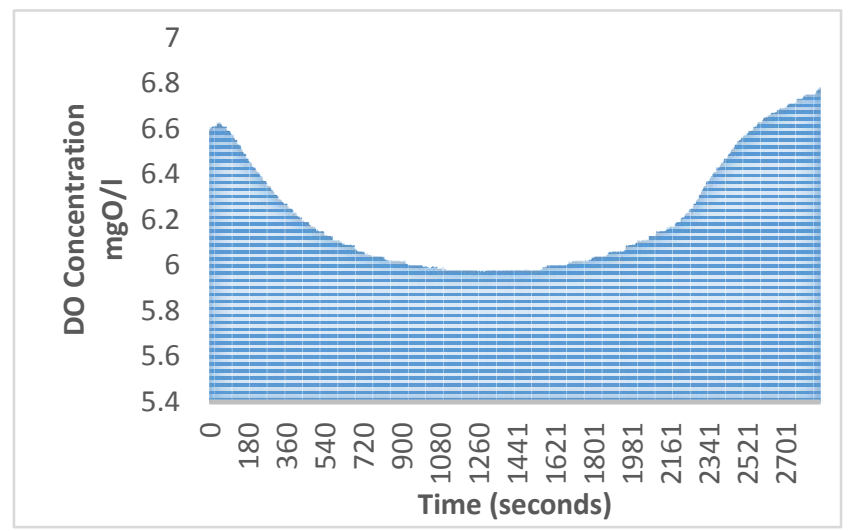

Fig. 2 Dissolved oxygen response due to the addition of acetate

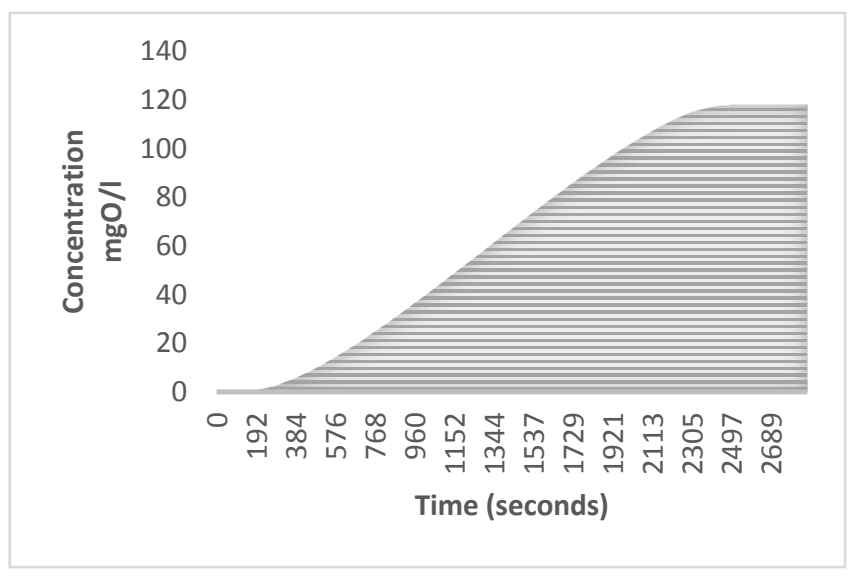

Fig. 3 Consumed Oxygen response due to the addition of acetate

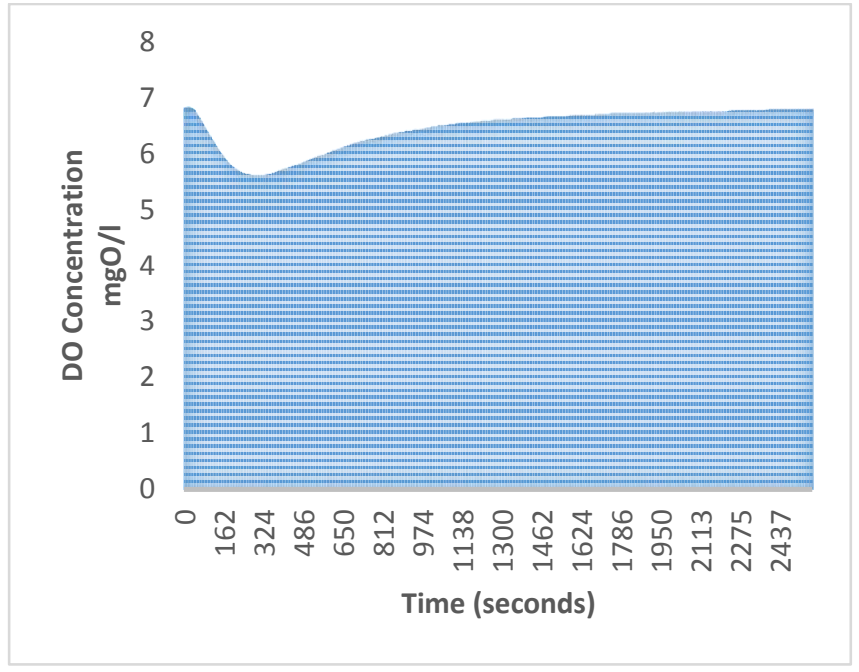

Fig. 4 Dissolved oxygen response due to the addition of $24 \mathrm{hr}$ composite sample

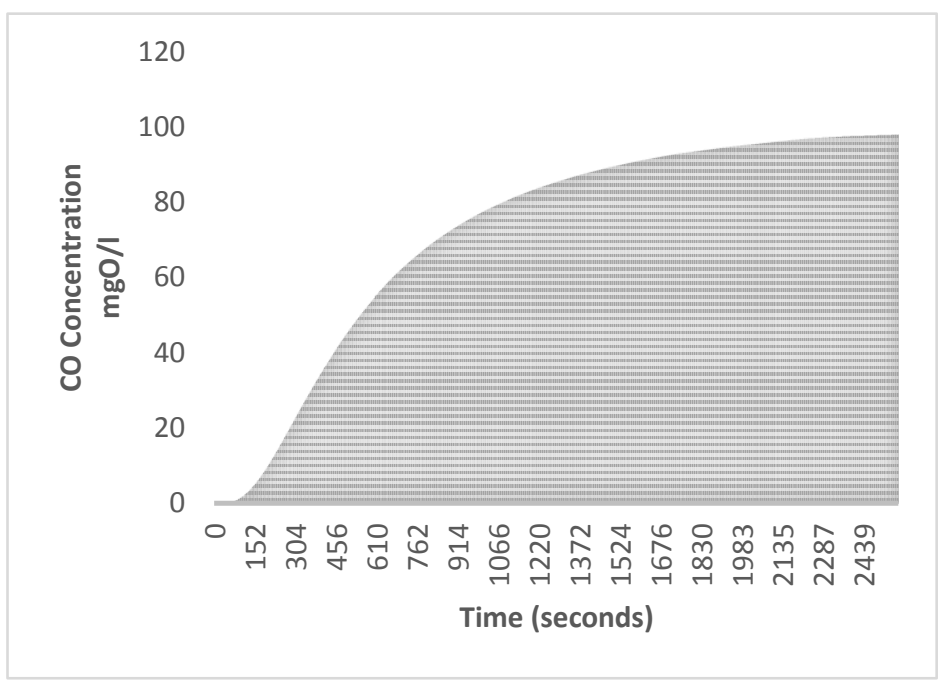

Fig. 5 Consumed oxygen response due to addition of $24 \mathrm{hr}$ composite sample

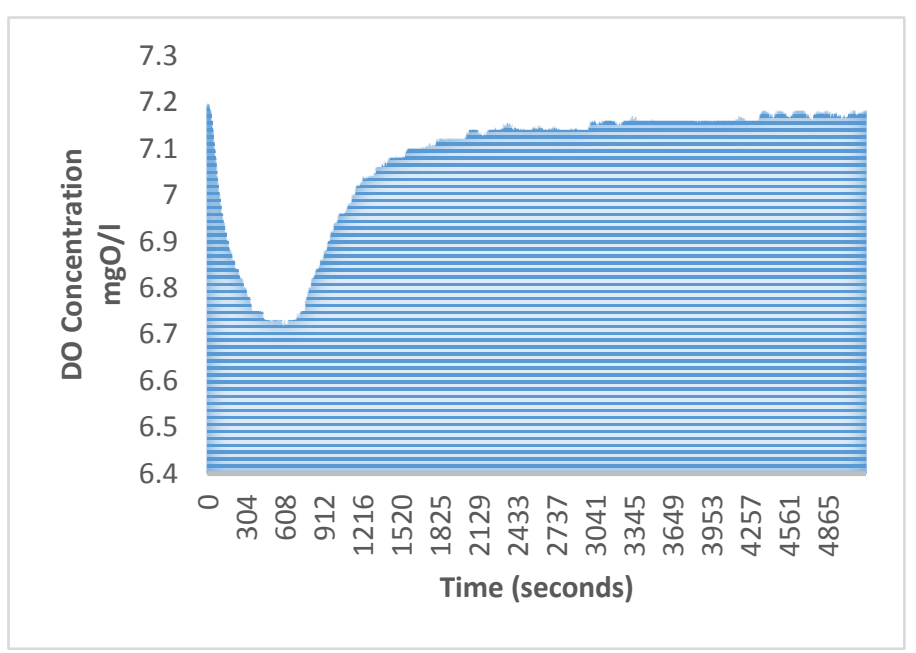

Fig. 6 Dissolved oxygen response due to the addition of the $24 \mathrm{hr}$ filtered composite sample 


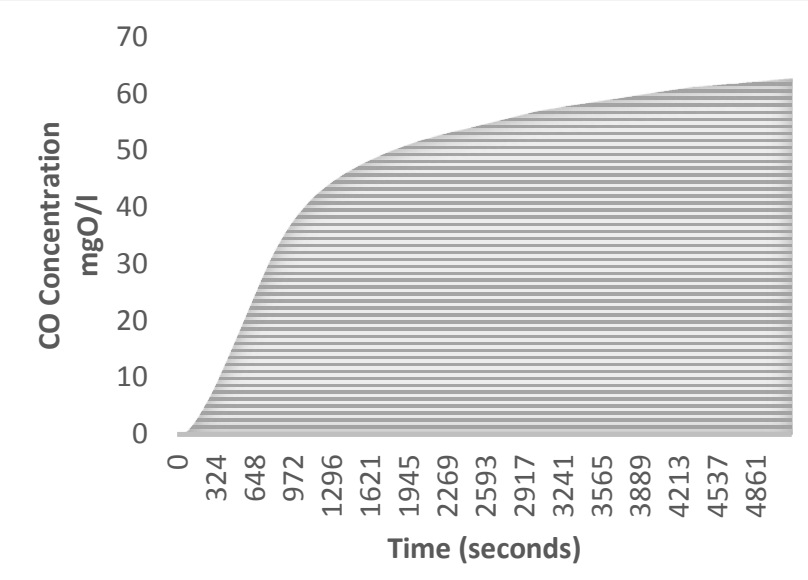

Fig. 7 Consumed oxygen response due to the addition of $24 \mathrm{hr}$ filtered composite sample

\section{Fractionation}

Several methods have been developed for COD characterization, but the two most commonly used processes are the biological and physio-chemical characterizations. The COD fractionation results are represented in Fig. 8. The COD fractions were expressed as percentages of the average experimental tests conducted to serve as input into the WEST model.

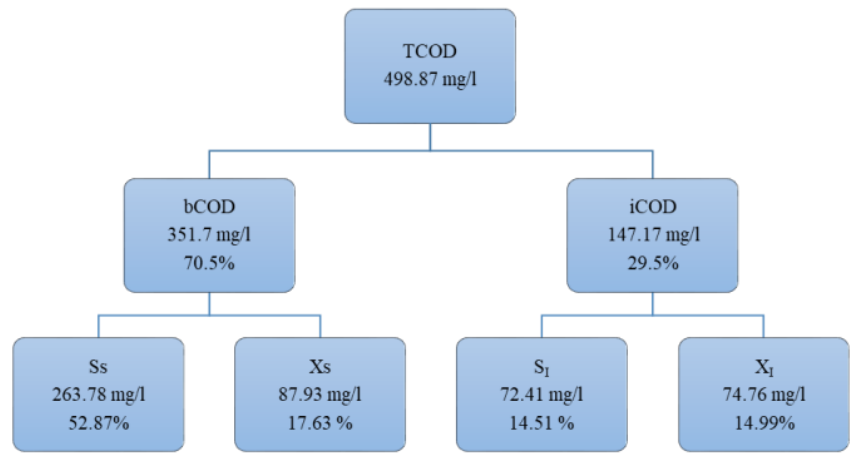

Fig. 8 COD Average Fractions that will serve as input for ASM

On average the primary wastewater effluent bCOD was found to be higher than the iCOD and Ss was higher than Xs. The Ss is the most valued substrate as it is easier for the microorganisms to breakdown. This therefore means that the WWTP primary wastewater effluent has sufficient substrate for the removal of COD and the removal of $\mathrm{N}$ and $\mathrm{P}$. The primary wastewater effluent of the WWTP has characteristics largely similar to municipal wastewater as the amount of bCOD was $70.5 \%$ and domestic wastewater was averaged by [10] to be $75 \%$; however, it is seen that the Ss fraction is significantly higher $(52.87 \%)$ than the Xs fraction (17.63\%). This can be directly linked to the industrial effluent coming into the plant (see Table I). Oil and Dairy industries have a higher Ss content combined.

Particulate organic matter which is Xs was found to be $17.63 \%$. The lower fraction is beneficial for the treatment process as this fraction is degraded slowly by a series of microbial actions, such as adsorption, hydrolysis, and metabolism [6], [7], [12]. The $\mathrm{S}_{\mathrm{I}}$, was found to be $14.51 \%$ of the TCOD and $X_{I}$ was $14.99 \%$. The $S_{I}$ and $X_{I}$ are refractory in biodegradation and are contained mostly in industrial effluents and can pass through the microbial wall but cannot be degraded due to its refractory nature. As a result, the $S_{I}$ and $X_{I}$ leave the activated sludge reactor unaltered in concentration and characteristics [22]. The WWTP's SI fraction is comparable to municipal wastewater with significant share of industrial wastewater (Table I). This shows that the WWTP receives both industrial and domestic effluent. The $X_{I}$ fraction becomes absorbed in the activated sludge removed from the system during the wasting process. The $\mathrm{X}_{\mathrm{I}}$ significantly affects the volume of wasted sludge and forms part of considerations for WWTP reactor design [20]. The $S_{I}$ and $X_{I}$ cannot be biologically degraded further in a WWTP and therefore can pass through the activated sludge system unchanged. Hence, precise COD fractionation is important for the efficient operation, optimization and modelling of wastewater treatment processes.

\section{ACKNOWLEDGMENT}

The Author expresses their sincere appreciation the Author's Supervisors for their never ending guidance, wholehearted encouragement and valuable critiques of this research work, family for their support and patience through the study, Sons for always understanding and allowing moments the solitude to complete work. The Author would mostly like to thank and give praise to the Lord "all mighty" who has given strength and intellect to undertake this study.

\section{REFERENCES}

[1] N.H. Tran, H. H. Ngo, T. Urase and K. Y. Gin. (2015). A critical review on characterization strategies of organic matter for wastewater and water treatment processes. Bioresource Technology. [Online]. 193. pp. 523533. Available: http://dx.doi.org/10.1016/j.biortech.2015.06.091

[2] V. Naidoo, "Municipal wastewater characterization: Application of denitrification batch tests," Ph.D. dissertation, Dept. Chemical. Eng., Natal Univ., Durban, South Africa, 1999.

[3] W. Gujer, M. Henze, T. Mino, T. Matsuo, M. C. Wentzel and GvR. Marais. (1995). The activated sludge model no. 2: biological phosphorus removal. Wat. Sci. Tech. [Online]. 31. pp. 1-11. Available: https://doi.org/10.1016/0273-1223(95)00175-M

[4] M. Henze, C. P. L. Grady Jr, W. Gujer, GvR. Marais and T. Matsuo. (1987). A general model for single sludge wastewater treatment systems. Wat. Res. [Online]. 21. pp. 505-515. Available: http://orbit.dtu.dk/files/7723380/lth1987_004.pdf

[5] P. L. Dold and GvR. Marais. (June 1986). Evaluation of the general activated sludge model proposed by the IAWPRC task group. Wat. Sci. Tech. [Online]. 18. pp. 63-89. Available: https://doi.org/10.2166/wst.1986.0061

[6] M.C. Wentzel, A. Mbewe, M.T. Lakay and G.A., Ekama. (July 1999). Batch test for characterization of the carbonaceous materials in municipal wastewaters. Water SA. [Online]. 25(3). pp. 327-335. Available: $\quad$ http://www.wrc.org.za/wpcontent/uploads/mdocs/WaterSA_1999_03_jul99_p327.pdf

[7] Z. Hu, K. Chandran, F.S. Barth and G. Domenico (February 2002). Evaluation of a rapid physical-chemical method for the determination of extant soluble COD. Wat. Res. [Online]. 36. pp. 617-624. Available: https://doi.org/10.1016/S0043-1354(01)00273-1

[8] D. Orhon and E.U. Çokgör (March 1999). COD fractionation in wastewater characterization-the state of the art. J. Chem. Technol. Biotechnol. [Online]. 68. pp. 283-293. Available: https://doi.org/10.1002/(SICI)1097-4660(199703)68:3<283::AIDJCTB633>3.0.CO;2-X

[9] E. Dulekgurgen, S. Doğruel, Ö. Karahan, D. Orhon. (January 2006). Size distribution of wastewater COD fractions as an index for 
biodegradability. Wat. Res. [Online]. 40. pp. 273 - 282. Available: https://doi.org/10.1016/j.watres.2005.10.032

[10] M. Henze, M.M.C., Van Loosdrecht. G.A. Ekama and D. Brdjanovic. Biological Wastewater Treatment, Principles, Modelling and Design. London.: IWA Publishing, 2008, pp. 1-511

[11] M. Speârandio and P. Etienne (March 2000). Estimation of wastewater biodegradable COD fractions by combining respirometric experiments in various So/Xo ratios. Wat. Res. [Online]. 34(4), pp. 1233-1246. Available: https://doi.org/10.1016/S0043-1354(99)00241-9

[12] E. Płuciennik-Koropczuk and S. Myszograj (July 2019). New approach in cod fractionation methods. Water. [Online]. 11(7), pp. 1484. Available: https://doi.org/10.3390/w11071484

[13] G. A. Ekama. and GvR. Marais. (1979). Dynamic behaviour of the activated sludge process. Journal WPC. [Online]. 51(3), pp. 534-556. Available: https://www.jstor.org/stable/25039863

[14] G. A. Ekama, P. L. Dold and GvR. Marais (June 1986). Procedures for determining influent COD fractions and the maximum specific growth rate of heterotrophs. Water Sci Technol. [Online]. 18(6). pp. 91-114. Available: https://doi.org/10.2166/wst.1986.0062

[15] S. Myszograj, E. Płuciennik-Koropczuk, A. Jakubaszek and A. Świętek. (May 2017). COD fractions - methods of measurement and use in wastewater treatment technology. CEER. [Online]. 24 (1). pp. 195-206. Available: https://doi.org/10.1515/ceer-2017-0014

[16] S. Sözen, E.U. Çokgör, D. Ohron and M. Henze. (February 1998). Respirometric analysis of activated sludge behavior-II. Heterotrophic growth under aerobic and anoxic conditions. Wat. Res. [Online]. 32(2). pp. 476-488. Available: https://doi.org/10.1016/S0043-1354(97)002108

[17] A. Baban, A. Yediler, N.K. Ciliz and A. Kettrup. (November 2004). Biodegradability oriented treatability studies on high strength segregated wastewater of a woolen textile dyeing plant. Chemosphere. [Online]. 57(7). pp. 731-738. Available: https://doi.org/10.1016/j.chemosphere.2004.05.038

[18] J. Struk-Sokołowska and J. Tkaczuk. (July 2018). Analysis of bakery sewage treatment process options based on COD fraction changes. J. Ecol. Eng. [Online]. 19(4). pp. 226-235. Available: https://doi.org/10.12911/22998993/89653

[19] A. Chiavola, G. Farabegoli and F. Antonetti. (April 2014). Biological treatment of olive mill wastewater in a sequencing batch reactor. Biochem. Eng. J. [Online]. 85. pp. 71-78. Available: https://doi.org/10.1016/j.bej.2014.02.004

[20] Y.Y. Choi, S.R. Baek, J.I. Kim, J.W. Choi, J. Hur, T.U. Lee, C.J. Park, B. Lee, (June 2017). Characteristics and biodegradability of wastewater organic matter in municipal wastewater treatment plants collecting domestic wastewater and industrial discharge. Water. [Online]. 9(6). Pp. 409. Available: https://doi.org/10.3390/w9060409

[21] A.W. Muller, M.C. Wentzel and G.A. Ekama (December 2007). Experimental determination of the heterotroph anoxic yield in anoxicaerobic activated sludge systems treating municipal wastewater. Water SA. [Online]. 30(5). pp. 7-12. Available: https://10.4314/wsa.v30i5.5111

[22] J. Wu, G. Yan, G. Zhou and T. Xu (December 2014). Wastewater COD biodegradability fractionated by simple physical-chemical analysis. Chemical Engineering Journal [Online]. 258 (10) 450-459. Available: https://doi.org/10.1016/j.cej.2014.07.106 